\title{
Regional-scale abrupt Mid-Holocene ice sheet thinning in the western Ross Sea, Antarctica
}

\author{
R. S. Jones, R. J. Whitmore, A. N. Mackintosh, K. P. Norton, S. R. Eaves, J. Stutz, M. Christl
}

\section{Supplemental Material}

\section{SAMPLE COLLECTION}

A total of 49 samples were collected in January 2016 for ${ }^{10} \mathrm{Be}$ surface-exposure dating at three sites in the lower reaches of Mawson Glacier (Supplemental Table 1). Bruce Point and Mount Murray - $9 \mathrm{~km}$ downstream and 2-4 km upstream of the modern grounding line - were chosen for elevation transects to capture a history of ice surface lowering during the Holocene. We assumed that these sample locations were likely overrun by warm-based, erosive ice in the past, which plucked bedrock located upstream and progressively deposited and exposed cobbles at the sites as the glacier thinned.

Bruce Point is a high-relief nunatak (peak at $315 \mathrm{~m}$ asl) with steep, stair-stepped flanks that extend down to Mawson Glacier's present-day Nordenskjöld Ice Tongue. Rock benches at the site are glacially moulded, striated and wind-swept, and provide stable locations for glaciallytransported erratic cobbles to be deposited. We collected 25 quartz-bearing cobbles in a transect up to $\sim 250 \mathrm{~m}$ above the modern ice surface (Fig. S1A).

Mount Murray is a topographically complex nunatak. It has a high mountain peak (990 m asl) surrounded by an extensive moderate-relief plateau (up to $365 \mathrm{~m}$ asl). The gently sloping bedrock adjacent to the present-day glacier surface is glacially-moulded, striated, weathered, wind-swept, and has locally developed snow patches. Erratic cobbles can be found from close to the ice surface to $\sim 200 \mathrm{~m}$ above the ice surface, however, the bedrock is frost-shattered at these higher elevations, indicative of long-term periglacial processes and limited glacial erosion. We therefore collected samples in a transect from the glacier surface to $\sim 160 \mathrm{~m}$ above the ice surface. The elevation transect consisted of 21 quartz-bearing cobbles from a series of smaller, closely-spaced transects (Fig. S1B); the most upstream set of samples were located at elevations 1-55 $\mathrm{m}$ above the modern ice surface and the more downstream set of samples occupied 96-152 $\mathrm{m}$ above the ice. 
A suite of lateral moraines can also be found adjacent to the modern ice margin, near to the lowest section of the Mount Murray elevation transect (Fig. S1C). The best preserved and most continuous of the moraines was $\sim 10 \mathrm{~m}$ from the ice margin, $\sim 2-3 \mathrm{~m}$ wide and $\sim 1 \mathrm{~m}$ high. We sampled the rock surface of 3 boulders perched on the moraine crest in order to date when the glacier was last more extensive than today.

The samples that we collected were sandstone, granite or granodiorite. Faceted, striated and bullet-shaped clasts were preferred as they are indicative of relatively recent glacial transport. We also avoided clasts with clear signs of surface weathering, such as spallation and pitting (>3 mm). Most cobble samples were collected in their entirety, but larger cobbles and the moraine boulders were sampled with a rock saw. We used a Makita battery-powered (18V) angle grinder and a petrol-powered circular saw to cut ladder-shaped grids into the rock surfaces. Pieces $(\sim 2-4 \mathrm{~cm}$ thick) were then removed with a hammer and chisel.

For each sample we described its glaciological and geomorphological context, noted the surface characteristics, measured the topographic shielding of the surface (using a compass and clinometer), and recorded its location. The latitude, longitude and altitude of the samples were measured using a Trimble GeoXH, which were post-processed using regional GPS base station corrections to provide altitude measurements with improved accuracy relative to the geoid (approximately mean sea level); the vertical accuracy of the GPS measurements was within $2 \mathrm{~m}$. The altitude of the modern ice surface was similarly measured at multiple locations at the base of the Bruce Point and Mount Murray elevation transects in order to provide estimates of past ice thickness change relative to today for comparison to other transects. 


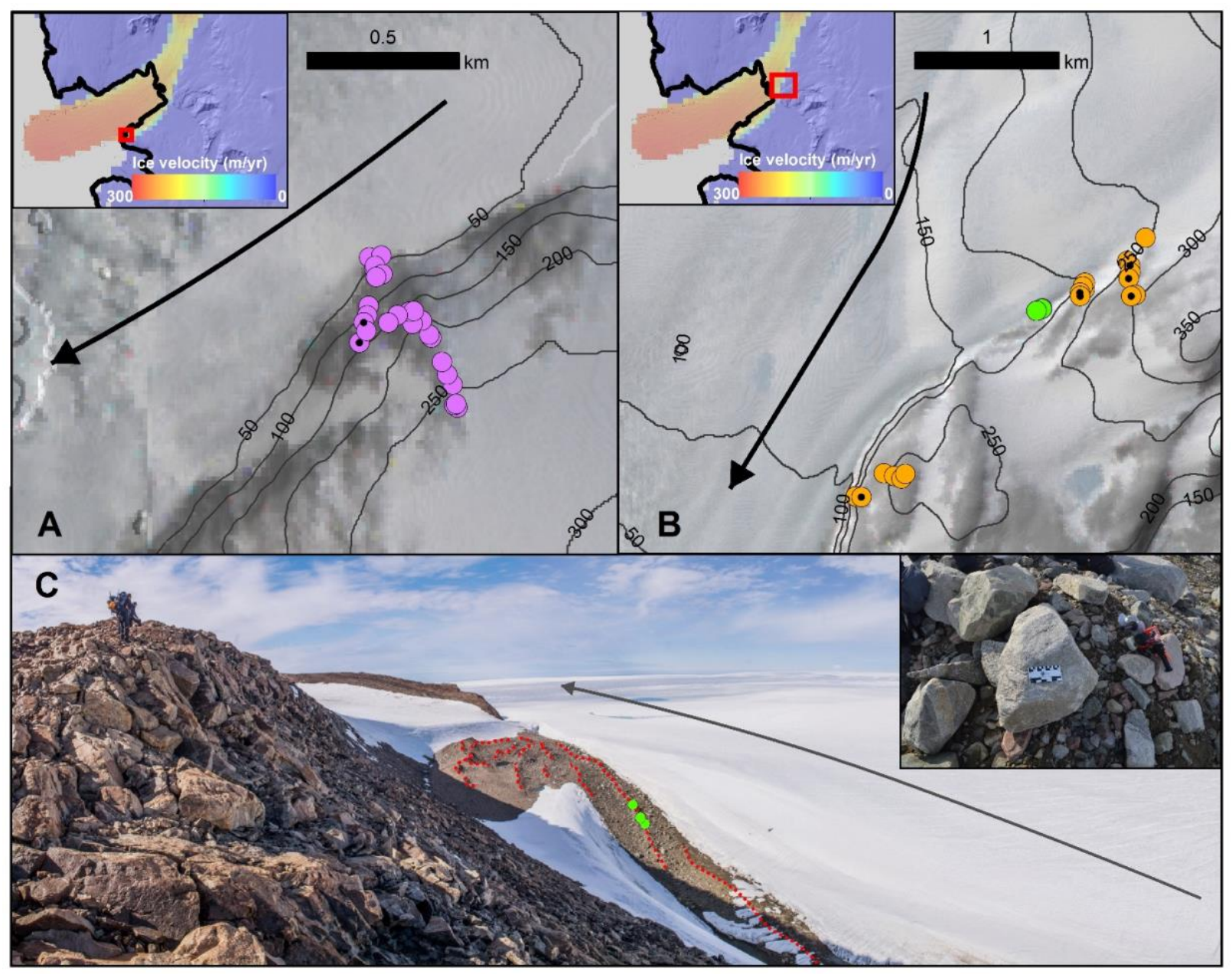

Figure S1. Mawson Glacier sample locations. Map view of A: Bruce Point (elevation transect as purple markers) and B: Mount Murray (elevation transect as orange markers, moraine as green markers). The insets show the ice velocity (Rignot et al., 2011) for the lower reaches of Mawson Glacier, with the respective study areas as red boxes. The principle ice flow direction is highlighted with a bold arrow, and surface contours from REMA (Howat et al., 2019) are displayed at 50-m intervals. Black dots depict samples that we identified as probable outliers (see text for details). C: The moraine complex at Mount Murray, with ridge crests highlighted with dashed red lines and the sampled boulders shown as green circles. The inset shows sample MM-16-31-M from above (boulder is $\sim 75 \mathrm{~cm}$ wide).

\section{SAMPLE PROCESSING AND MEASUREMENT}

The rocks were physically and geochemically processed at the sedimentology and cosmogenic nuclide laboratories at Victoria University of Wellington in order to isolate quartz and extract ${ }^{10} \mathrm{Be}$ in the collected samples. The upper $\sim 1.5-8 \mathrm{~cm}$ of each sample was extracted for processing using a large circular saw. This material was then crushed with a fine jaw- 
crusher and sieved to retain sand-sized grains $(250 \mu \mathrm{m}-1 \mathrm{~mm})$. Several mineral separation techniques were utilized to separate the quartz from other minerals present in the crushed bulk sample. These included paramagnetic and diamagnetic separation using a Frantz Isodynamic separator, heavy liquid separation, and froth-floatation mineral separation. The samples were chemically processed once enough monomineralic quartz was obtained (>20 g). We utilized a modified version of the chemical cleaning and digestion protocol that was developed by von Blanckenburg et al. (1996) and von Blanckenburg et al. (2004). Initial leaching was done with a combination of several rounds $10 \%$ hydrochloric acid and $5 \%$ mixtures of hydrofluoric acid and nitric acid to remove any non-quartz minerals and to etch meteoric beryllium from the outer surface of the grains; the leaching phase was complete when at least $20 \%$ sample mass loss had occurred. A final 1-hour hydrofluoric acid (7 M) leach and concentrated aqua regia cleaning was then carried out prior to sample dissolution.

The cleaned quartz samples were processed in 6 separate batches for beryllium extraction. A ${ }^{9} \mathrm{Be}$ spike was first added to each sample (1 batch used a $349 \mathrm{ppm}$ carrier solution and 5 batches used a $305 \mathrm{ppm}$ carrier solution), and the samples were then digested in concentrated hydrofluoric acid. Anion exchange columns were used to remove iron, and then cation exchange columns were used to isolate beryllium from iron, aluminium, titanium, sodium and magnesium. After column chemistry, the eluted beryllium was precipitated as hydroxide, calcined, mixed with niobium flux, and packed into targets for analysis with Accelerator Mass Spectrometry (AMS).

AMS measurements of ${ }^{10} \mathrm{Be} /{ }^{9} \mathrm{Be}$ were undertaken at ETH Zurich using the Tandy accelerator mass spectrometer (0.5 MV) (Christl et al., 2013) or PRIME Lab using the Tandem accelerator mass spectrometer (10 MV). The samples run at ETH Zurich were measured relative to the in-house standard S2007N (nominal ${ }^{10} \mathrm{Be} /{ }^{9} \mathrm{Be}$ ratio of $28.1 \pm 0.8 \times 10^{-12}$ ), which in turn was calibrated relative to the ICN 01-5-1 standard $\left({ }^{10} \mathrm{Be} /{ }^{9} \mathrm{Be}\right.$ ratio of $27.09 \pm 0.3 \times 10^{-}$ 12) (Nishiizumi et al., 2007), while the samples run at PRIME Lab were normalised relative to the 07KNSTD standard with a ${ }^{10} \mathrm{Be} /{ }^{9} \mathrm{Be}$ ratio of $8.56 \times 10^{-12}$ (Nishiizumi et al., 2007). All sample measurements were then corrected with batch-specific procedural blank concentrations $\left({ }^{10} \mathrm{Be} /{ }^{9} \mathrm{Be}\right.$ ratios ranged from $2.25 \times 10^{-15}$ to $\left.1.32 \times 10^{-14}\right)$. Two samples (MM16-10, MM-16-17) had measured ${ }^{10} \mathrm{Be}$ concentrations less than the procedural blank. Exposure ages could not be calculated from these samples, but such low concentrations are indicative of very recent exposure. 


\section{EXPOSURE AGE CALCULATIONS}

Surface-exposure ages were calculated from the measured concentrations of ${ }^{10} \mathrm{Be}$, which were corrected for topographic shielding, sample thickness and quartz density $\left(2.65 \mathrm{~g} \mathrm{~cm}^{3}\right)$. This was done with iceTEA (Jones et al., 2019a), which uses the calculation framework of CRONUScalc (Marrero et al., 2016), a recent global production rate dataset (Borchers et al., 2016) and the nuclide-specific scaling model LSDn (Lifton et al., 2014). The resulting ages assume zero erosion and no snow cover correction.

Changes in land elevation occurred through the last deglaciation in Antarctica as a result of glacial isostatic adjustment (GIA), potentially altering local nuclide production rates and, therefore, surface-exposure ages (Jones et al., 2019b). We evaluated this effect at our sample sites using the iceTEA elevation correction tool (Jones et al., 2019a), and ICE-6G (Argus et al., 2014; Peltier et al., 2015) and W12 (Whitehouse et al., 2012) models. The correction is small ( $<150$ years; $<1.5 \%)$ during the Holocene in our study area (Fig. S2), and so we report exposure ages uncorrected for GIA.

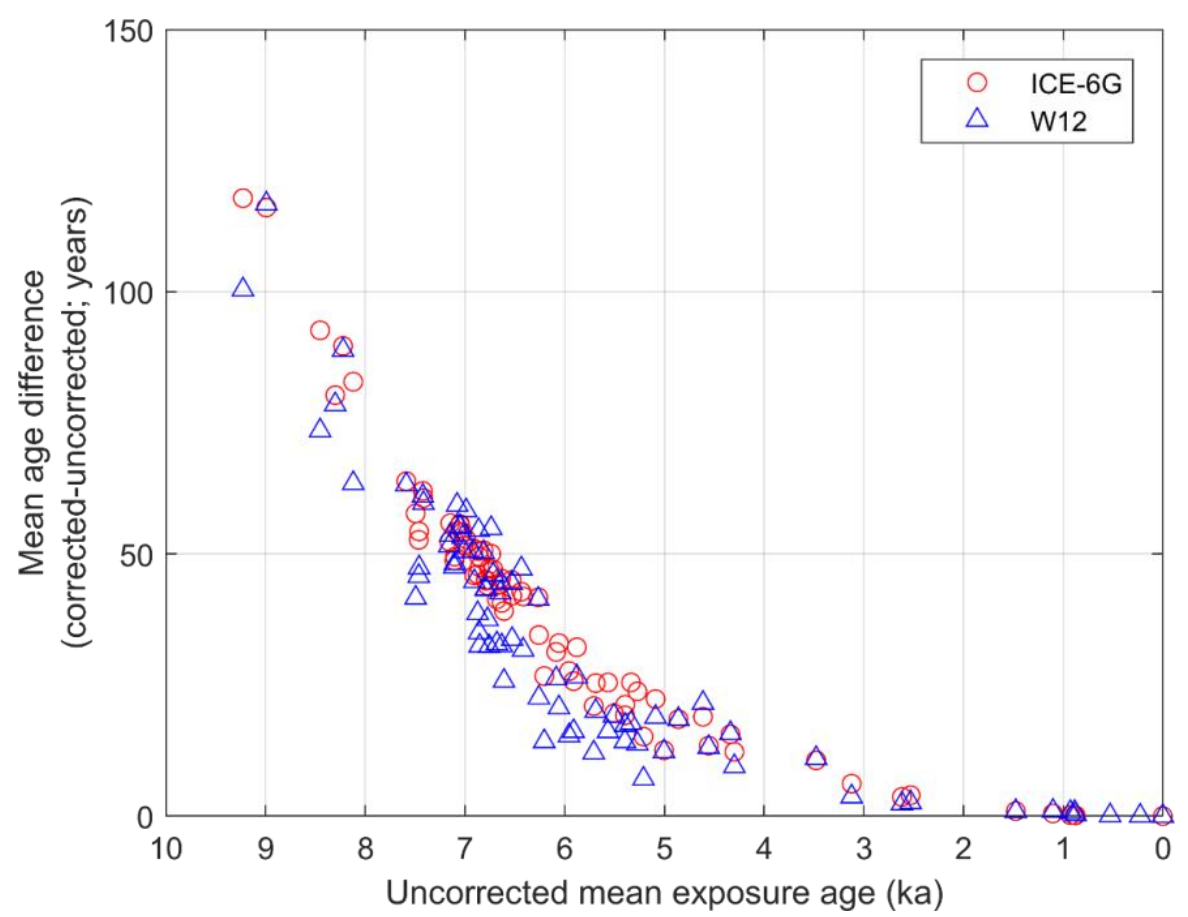

Figure S2. The difference between exposure ages that were corrected and uncorrected for GIA. Samples are shown from Mawson Glacier (this study) and Mackay Glacier (Jones et al., 2015). Two different models were used to compute the corrections: ICE-6G (Argus et al., 2014; Peltier et al., 2015) and W12 (Whitehouse et al., 2012). The magnitude of the corrections decreases through the 
Holocene towards present, with the maximum potential correction in this area of $<150$ years (equivalent to $<1.5 \%$ ).

The exposure ages at Mawson Glacier range from 51.9 $\pm 4.2 \mathrm{ka}(\mathrm{MM}-16-30)$ to $530 \pm 580$ years (MM-16-32-M) ago, with most ages clustered between approximately 5 and $8 \mathrm{ka}$ (Supplemental Table 1; Figs. S3 and S4). We identify 11 samples as probable outliers in the elevation transects (Fig. S3). At Mount Murray, 7 samples have apparent exposure ages prior to $20 \mathrm{ka}$ (MM-16-02, MM-16-15, MM-16-16, MM-16-24, MM-16-27, MM-16-28, MM-1630). These ages likely record the inheritance of ${ }^{10} \mathrm{Be}$ from a previous episode of exposure and, therefore, are not indicative of ice surface lowering during the last deglaciation. The majority of these samples were from the higher elevation parts of the upstream end of the Mount Murray transect, where a thinner and slower-flowing portion of the glacier would have overridden the nunatak. Such areas are more prone to cosmogenic inheritance as the potential for glacial erosion is reduced and the removal of old glacial material from the system is less likely. Similarly at Bruce Point, three samples (BP-16-25, BP-16-09, BP-16-06) are older than the main cluster of exposure ages, likely reflecting some degree of cosmogenic inheritance. We also identify another probable outlier in the Mount Murray transect (MM-1603), which is slightly younger than and not stratigraphically consistent with ages at similar elevations; this age could reflect post-depositional movement and/or surface erosion. The remaining ages record rapid thinning from ca. $8 \mathrm{ka}$ to $5 \mathrm{ka}$ at Bruce Point and ca. $6 \mathrm{ka}$ to $5 \mathrm{ka}$ at Mount Murray.

Three samples at Mount Murray potentially record final thinning at ca. 3.3 to $2.2 \mathrm{ka}$. Lastly, the two samples with very low ${ }^{10} \mathrm{Be}$ concentrations (MM-16-10, MM-16-17) indicate that the last few meters of thinning occurred relatively recently. The low nuclide concentrations indicate that these samples did not experience significant inheritance and, therefore, these sites were likely overrun by warm-based, erosive ice in the past.

Three exposure ages that come from a moraine near Mount Murray (MM-16-31-M, MM-1632-M, MM-16-34-M) date to between $1.48 \pm 0.74 \mathrm{ka}$ and $0.53 \pm 0.57 \mathrm{ka}$ (Supplemental Table 1; Fig. S4). We applied the generalized Extreme Studentized Deviate outlier test and reduced chi-squared test that are described in Jones et al. (2019a) to evaluate the significance of this age population. None of the ages were identified as outliers using either a 0.01 or 0.05 significance interval (corresponding to a $1 \%$ or $5 \%$ chance of incorrectly finding outliers). The calculated reduced chi-squared value (0.52) was less than the $\mathrm{K}$ criterion (3.0), implying 
that the ages can be considered as a single population. We therefore use the weighted mean and standard deviation of the population (at 1 standard deviation) to represent when the ice margin was at this moraine.
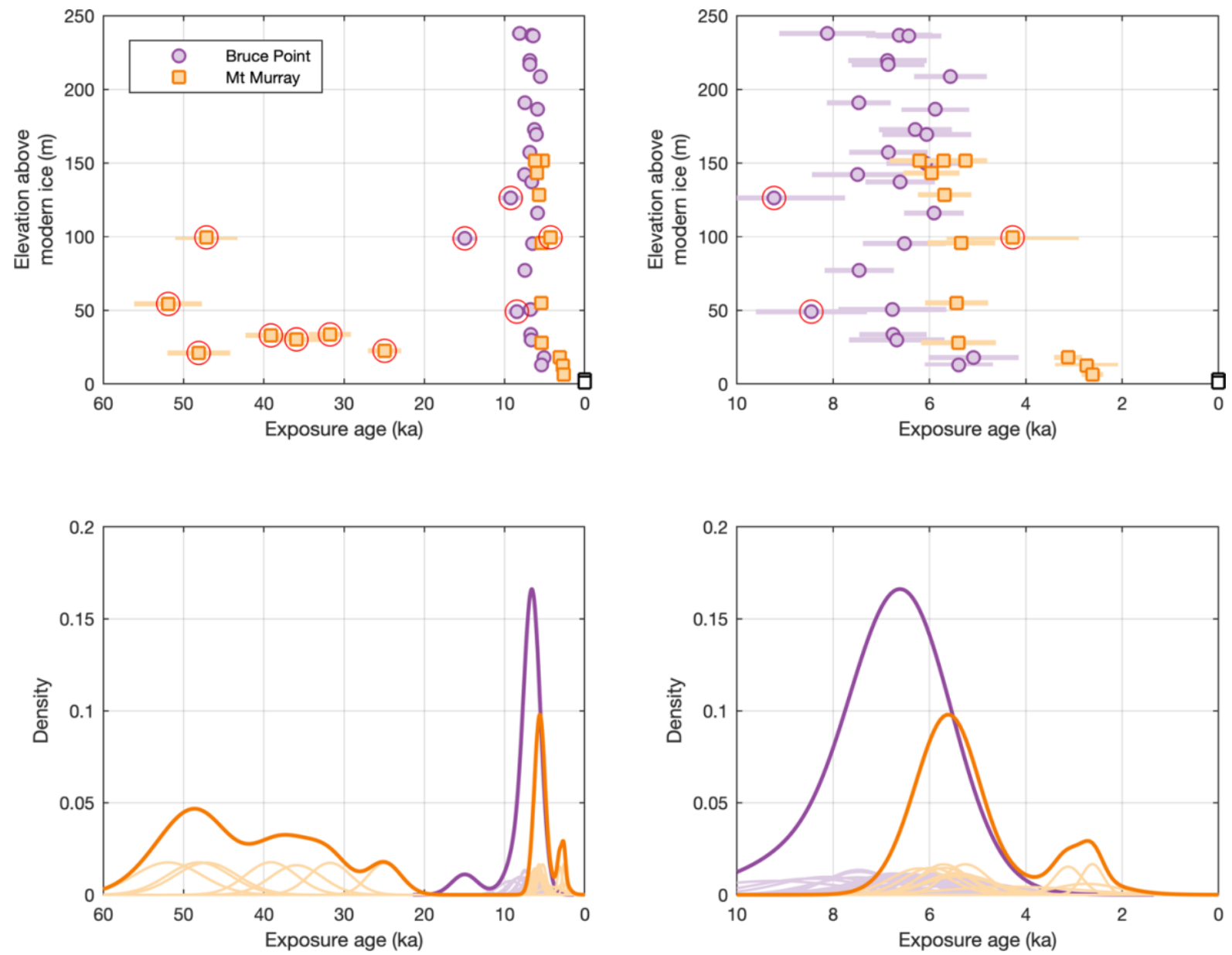

Figure S3. Exposure ages from Bruce Point (purple) and Mount Murray (orange) shown as elevation transects (upper panel) and kernel density estimates (lower panel). The right panel shows the same data but for just the last $10 \mathrm{ka}$. Most ages are clustered between ca. 4.5 and $8 \mathrm{ka}$. Potential outliers are highlighted with red circles. Two samples that were collected next to the modern ice surface at Mount Murray had too small concentrations to calculate exposure ages, which are plotted as white squares at $0 \mathrm{ka}$. 


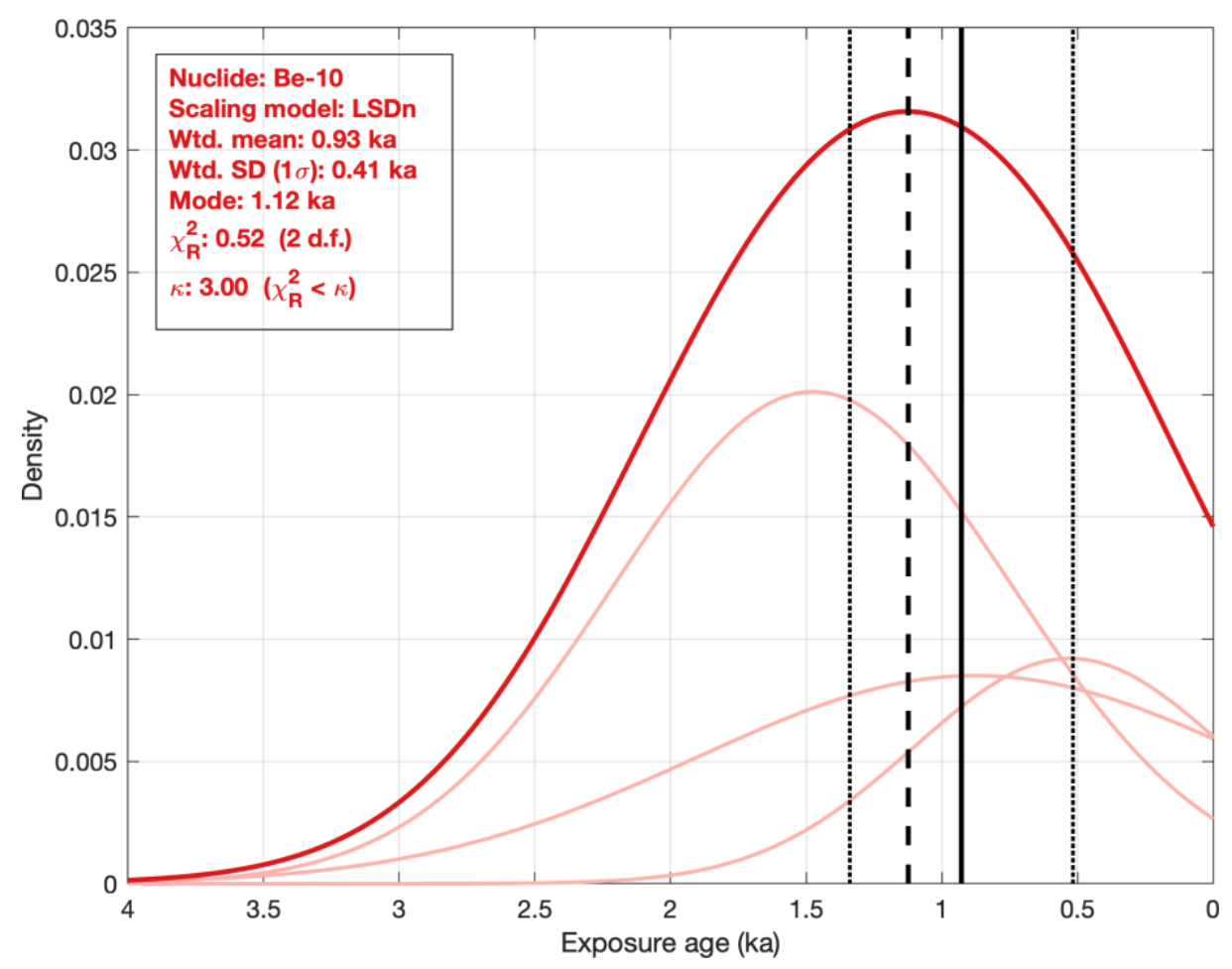

Figure S4. Moraine ages plotted as kernel density estimates, with the bold curve representing the summed probability of the age population. The plot and reduced chi-squared values were generated using iceTEA (Jones et al., 2019a).

\section{REGRESSION ANALYSIS OF ABRUPT THINNING EPISODE}

We performed linear regression analysis for the period ca. 8-4.5 ka in each of the elevation transects to derive rates of abrupt thinning at Mawson Glacier. Weighted least squares regression was applied randomly to the exposure ages (at $2 \sigma$ ) through a Monte Carlo simulation (10,000 iterations), as described in (Johnson et al., 2014; Jones et al., 2015; Jones et al., 2019a). We excluded the outliers mentioned above, as well as the set of Mount Murray ages at ca. 2.2-3.3 ka, in the analyses. The computed average rate of thinning during this time period (at 95\% confidence) was $0.15-4.37 \mathrm{~m} \mathrm{yr}^{-1}$ (best-fit of $0.35 \mathrm{~m} \mathrm{yr}^{-1}$ ) and $0.10-4.16 \mathrm{~m} \mathrm{yr}^{-1}$ (best-fit of $0.26 \mathrm{~m} \mathrm{yr}^{-1}$ ) for Bruce Point and Mount Murray, respectively (Fig. S5). The corresponding duration of this abrupt thinning event was calculated using the difference in timing between the start and end of the random regression simulations. Figure S6 shows approximate best-fit durations of 705 and 515 years for Bruce Point and Mount Murray.

Based on the regression analysis, the period of abrupt thinning at Mount Murray appears to lag that recorded at Bruce Point and at the Mackay Glacier transects by 200-1,300 years. This offset may be explained by glaciological or geochronological factors: 1) dynamic adjustment 
of the glacier in response to a perturbation at the terminus can vary due to differences in the bed topography and glacier geometry (Felikson et al., 2017; Vieli and Nick, 2011), thus the timing and magnitude of glacier thinning may not share the exact same style and timing across sites; and/or 2) the exposure ages at Bruce Point could have been affected by cosmogenic micro-inheritance, which would make some of the apparent ages slightly too old and may explain the degree of age scatter at that site.
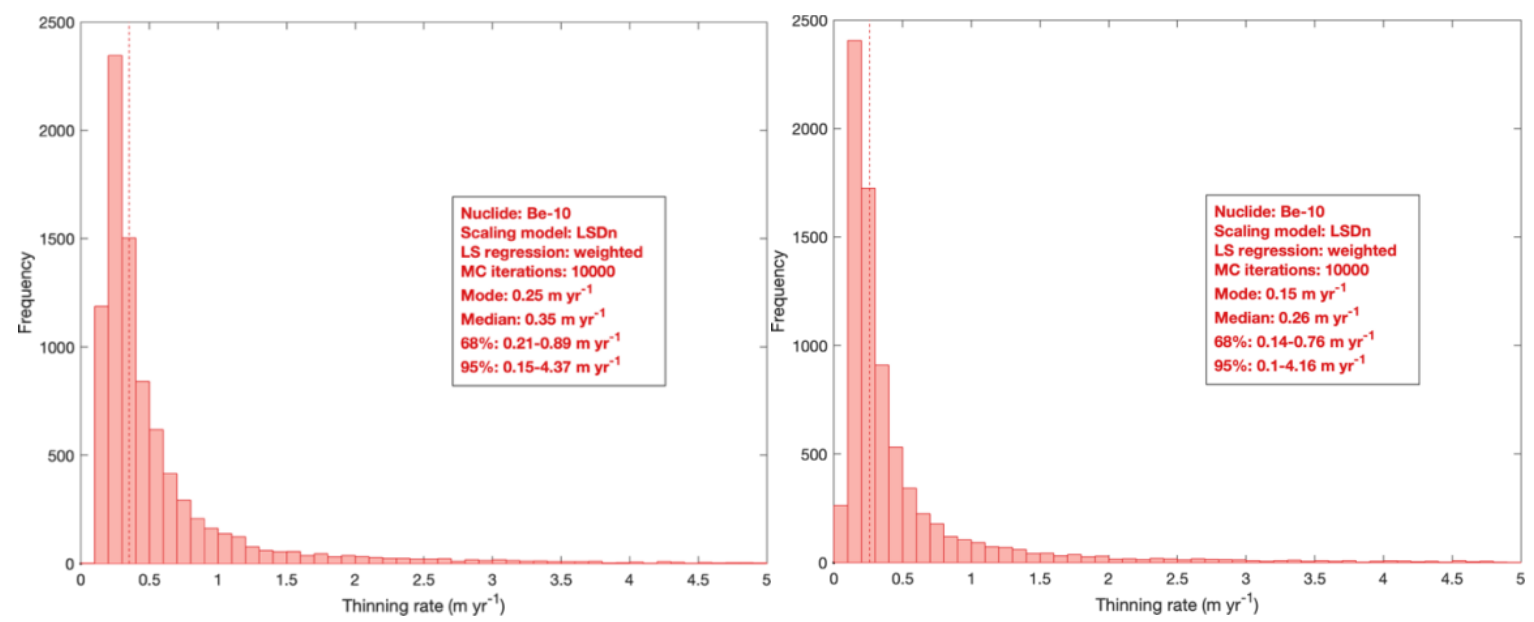

Figure S5. Rates of abrupt thinning at Bruce Point (left) and Mount Murray (right). The analysis used weighted least squares (LS) regression and 10,000 Monte Carlo (MC) iterations. The best-fit (median) rates (dotted lines) are 0.35 and $0.26 \mathrm{~m} \mathrm{yr}^{-1}$, respectively. iceTEA was used to performed the analysis and produce the plots (Jones et al., 2019a).

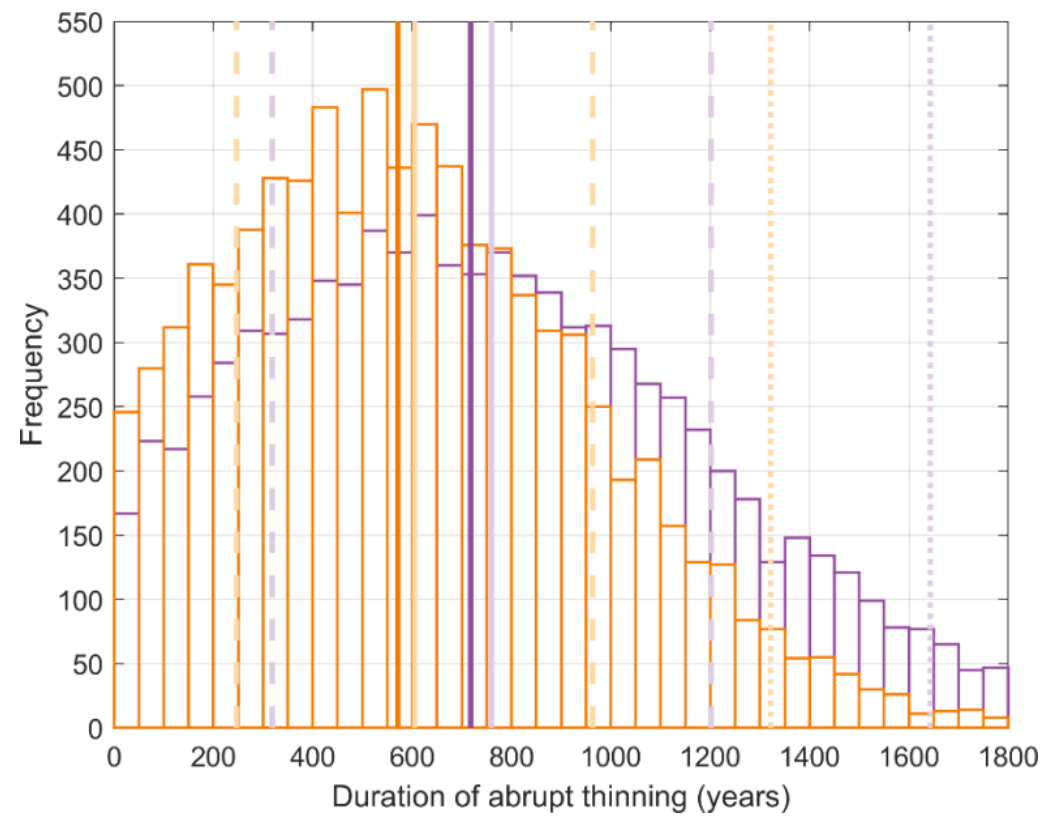


Figure S6. Durations of abrupt thinning at Bruce Point (purple) and Mount Murray (orange) corresponding to the rates in Figure S5. The best-fit (median) durations (dark solid lines) are 705 and 515 years, respectively. The means with $1 \sigma$ and $2 \sigma$ are shown as light solid, dashed and dotted lines.

\section{DATA-MODEL COMPARISON}

We have compiled ice sheet model outputs from five recent studies (Golledge et al., 2014; Kingslake et al., 2018; Lowry et al., 2019; Pollard et al., 2016; Pollard et al., 2018) to show the current state of deglacial model simulations for the Scott Coast of Southern Victoria Land (Fig. S7). We extracted data using a reference point that is $\sim 5 \mathrm{~km}$ south of Bruce Point in the middle of fast flowing ice on the Nordenskjöld Ice Tongue of Mawson Glacier $\left(-76.195^{\circ} \mathrm{S}\right.$, longitude $\left.162.417^{\circ} \mathrm{E}\right)$. Some of the data were derived using the Antarctic Data-Model Comparison interface (http://dmc.ice-d.org/). The model outputs were then normalized to present-day (year 0) to compare relative ice thickness changes through time. Figure S7 shows the compiled model outputs, which do not provide a consistent ice sheet thinning history in the vicinity of Mawson Glacier over the last 15 thousand years. In particular, the timing, rate and magnitude of thinning greatly differs between models, with outputs showing a mixture of abrupt thinning, gradual thinning, and variable thinning and thickening. This mismatch between ice sheet simulations highlights the need for improved geological constraints from terrestrial sites along the Victoria Land coast of the southwestern Ross Sea.

We can also evaluate these different ice sheet model simulations against our new exposure ages (Fig. S7). The data-model comparison shows that none of the models replicate the timing, rate and/or magnitude of ice sheet thinning that is recorded by at Mawson Glacier and Mackay Glacier. The lack of consistency between models and the mismatch with geological data highlight that ice sheet models are not currently able to simulate dynamic ice mass changes in this region associated with climate forcings and marine ice sheet instability. 


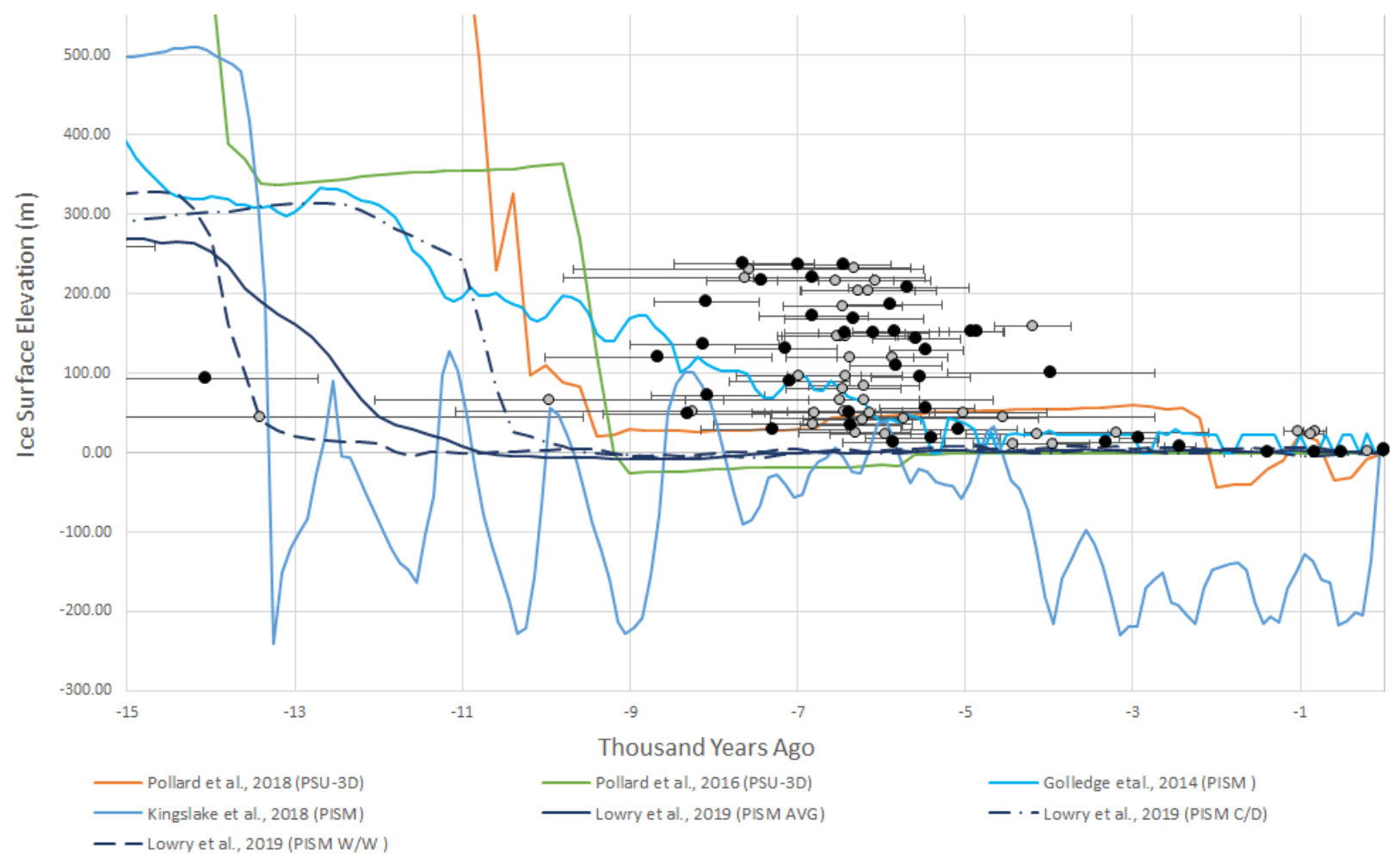

Figure S7. Data-model comparison for Mawson Glacier, southwestern Ross Sea. Ice sheet model outputs are shown for five different modelling studies (Golledge et al., 2014; Kingslake et al., 2018; Lowry et al., 2019; Pollard et al., 2016; Pollard et al., 2018). Those studies which used the Parallel Ice Sheet Model (PISM) are shown in shades of blue, while those that used the Pennsylvania State University 3D model (PSU-3D) are shown in red and orange colors. Three model scenarios are shown from Lowry et al., 2019: Cold /Dry, Warm/Wet, and the ensemble average. Here we show that modelling efforts in the area around Mawson Glacier do not agree on either the timing or rate of thinning. Our data from Mawson Glacier (black circles) is shown together with that from Mackay Glacier (grey circles; Jones et al., 2015).

\section{SUPPLEMENTARY REFERENCES CITED}

Argus, D. F., Peltier, W. R., Drummond, R., and Moore, A. W., 2014, The Antarctica component of postglacial rebound model ICE-6G_C (VM5a) based on GPS positioning, exposure age dating of ice thicknesses, and relative sea level histories: Geophysical Journal International, v. 198, no. 1, p. 537-563.

Borchers, B., Marrero, S., Balco, G., Caffee, M., Goehring, B., Lifton, N., Nishiizumi, K., Phillips, F., Schaefer, J., and Stone, J., 2016, Geological calibration of spallation 
production rates in the CRONUS-Earth project: Quaternary Geochronology, v. 31, p. 188-198.

Christl, M., Vockenhuber, C., Kubik, P., Wacker, L., Lachner, J., Alfimov, V., and Synal, H.A., 2013, The ETH Zurich AMS facilities: Performance parameters and reference materials: Nuclear Instruments and Methods in Physics Research Section B: Beam Interactions with Materials and Atoms, v. 294, p. 29-38.

Felikson, D., Bartholomaus, T. C., Catania, G. A., Korsgaard, N. J., Kjær, K. H., Morlighem, M., Noël, B., Van Den Broeke, M., Stearns, L. A., and Shroyer, E. L., 2017, Inland thinning on the Greenland ice sheet controlled by outlet glacier geometry: Nature Geoscience, v. 10, no. 5, p. 366.

Golledge, N. R., Menviel, L., Carter, L., Fogwill, C. J., England, M. H., Cortese, G., and Levy, R. H., 2014, Antarctic contribution to meltwater pulse 1A from reduced Southern Ocean overturning: Nature Communications, v. 5.

Howat, I. M., Porter, C., Smith, B. E., Noh, M.-J., and Morin, P., 2019, The Reference Elevation Model of Antarctica: The Cryosphere, v. 13, no. 2, p. 665-674.

Johnson, J. S., Bentley, M. J., Smith, J. A., Finkel, R., Rood, D., Gohl, K., Balco, G., Larter, R. D., and Schaefer, J., 2014, Rapid thinning of Pine Island Glacier in the early Holocene: Science, v. 343, no. 6174, p. 999-1001.

Jones, R., Mackintosh, A., Norton, K. P., Golledge, N. R., Fogwill, C., Kubík, P. W., Christl, M., and Greenwood, S. L., 2015, Rapid Holocene thinning of an East Antarctic outlet glacier driven by marine ice sheet instability: Nature Communications, v. 6, p. 8910.

Jones, R., Small, D., Cahill, N., Bentley, M., and Whitehouse, P., 2019a, iceTEA: Tools for plotting and analysing cosmogenic-nuclide surface-exposure data from former ice margins: Quaternary Geochronology, v. 51, p. 72-86.

Jones, R., Whitehouse, P., Bentley, M., Small, D., and Dalton, A., 2019b, Impact of glacial isostatic adjustment on cosmogenic surface-exposure dating: Quaternary Science Reviews, v. 212, p. 206-212.

Kingslake, J., Scherer, R., Albrecht, T., Coenen, J., Powell, R., Reese, R., Stansell, N., Tulaczyk, S., Wearing, M., and Whitehouse, P., 2018, Extensive retreat and readvance of the West Antarctic ice sheet during the Holocene: Nature, v. 558, no. 7710, p. 430. 
Lifton, N., Sato, T., and Dunai, T. J., 2014, Scaling in situ cosmogenic nuclide production rates using analytical approximations to atmospheric cosmic-ray fluxes: Earth and Planetary Science Letters, v. 386, p. 149-160.

Lowry, D. P., Golledge, N. R., Bertler, N. A., Jones, R. S., and McKay, R., 2019, Deglacial grounding-line retreat in the Ross Embayment, Antarctica, controlled by ocean and atmosphere forcing: Science Advances, v. 5, no. 8, p. eaav8754.

Marrero, S. M., Phillips, F. M., Borchers, B., Lifton, N., Aumer, R., and Balco, G., 2016, Cosmogenic nuclide systematics and the CRONUScalc program: Quaternary Geochronology, v. 31, no. Supplement C, p. 160-187.

Nishiizumi, K., Imamura, M., Caffee, M. W., Southon, J. R., Finkel, R. C., and McAninch, J., 2007, Absolute calibration of 10Be AMS standards: Nuclear Instruments and Methods in Physics Research Section B: Beam Interactions with Materials and Atoms, v. 258, no. 2 , p. $403-413$.

Peltier, W. R., Argus, D. F., and Drummond, R., 2015, Space geodesy constrains ice age terminal deglaciation: The global ICE-6G_C (VM5a) model: Journal of Geophysical Research: Solid Earth, v. 120, no. 1, p. 450-487.

Pollard, D., Chang, W., Haran, M., Applegate, P., and DeConto, R., 2016, Large ensemble modeling of the last deglacial retreat of the West Antarctic Ice Sheet: Comparison of simple and advanced statistical techniques: Geoscientific Model Development, v. 9, no. 5, p. 1697-1723.

Pollard, D., Gomez, N., DeConto, R., and Han, H., 2018, Estimating Modern Elevations of Pliocene Shorelines Using a Coupled Ice Sheet-Earth-Sea Level Model: Journal of Geophysical Research: Earth Surface, v. 123, no. 9, p. 2279-2291.

Rignot, E., Mouginot, J., and Scheuchl, B., 2011, Ice flow of the Antarctic ice sheet: Science, v. 333 , no. 6048 , p. $1427-1430$.

Vieli, A., and Nick, F. M., 2011, Understanding and modelling rapid dynamic changes of tidewater outlet glaciers: issues and implications: Surveys in Geophysics, v. 32, no. 45, p. 437-458.

von Blanckenburg, F., Belshaw, N., and O'Nions, R., 1996, Separation of 9Be and cosmogenic 10Be from environmental materials and SIMS isotope dilution analysis: Chemical Geology, v. 129, no. 1, p. 93-99. 
von Blanckenburg, F., Hewawasam, T., and Kubik, P. W., 2004, Cosmogenic nuclide evidence for low weathering and denudation in the wet, tropical highlands of Sri Lanka: Journal of Geophysical Research: Earth Surface (2003-2012), v. 109, no. F3.

Whitehouse, P. L., Bentley, M. J., Milne, G. A., King, M. A., and Thomas, I. D., 2012, A new glacial isostatic adjustment model for Antarctica: calibrated and tested using observations of relative sea-level change and present-day uplift rates: Geophysical Journal International, v. 190, no. 3, p. 1464-1482. 